\title{
Androgens in maternal vascular and placental function: implications for preeclampsia pathogenesis
}

\author{
Sathish Kumar ${ }^{1,2,3}$, Geoffrey H Gordon², David H Abbott ${ }^{2,3,4}$ and Jay S Mishra ${ }^{1}$ \\ ${ }^{1}$ Department of Comparative Biosciences, School of Veterinary Medicine, University of Wisconsin, Madison, \\ Wisconsin, USA, ${ }^{2}$ Department of Obstetrics and Gynecology, School of Medicine and Public Health, University of \\ Wisconsin, Madison, Wisconsin, USA, ${ }^{3}$ Endocrinology-Reproductive Physiology Program, University of Wisconsin, \\ Madison, Wisconsin, USA and ${ }^{4}$ Wisconsin National Primate Research Center, University of Wisconsin, Madison, \\ Wisconsin, USA
}

Correspondence should be addressed to S Kumar; Email: skumar82@wisc.edu

\begin{abstract}
Adequate maternal vascular adaptations and blood supply to the uterus and placenta are crucial for optimal oxygen and nutrient transport to growing fetuses of eutherian mammals, including humans. Multiple factors contribute to hemodynamics and structuring of placental vasculature essential for term pregnancy with minimal complications. In women, failure to achieve or sustain favorable pregnancy progression is, not surprisingly, associated with high incidence of antenatal complications, including preeclampsia, a hypertensive disorder of pregnancy. While the pathogenesis of preeclampsia in women remains unknown, a role for androgens is emerging. The relationship between androgens and maternal cardiovascular and placental function deserves particular consideration because testosterone levels in the circulation of preeclamptic women are elevated approximately two- to three-fold and are positively correlated with vascular dysfunction. Preeclampsia is also associated with elevated placental androgen receptor (AR) gene expression. Studies in animal models mimicking the pattern and level of increase of adult female testosterone levels to those found in preeclamptic pregnancies, replicate key features of preeclampsia, including gestational hypertension, endothelial dysfunction, exaggerated vasoconstriction to angiotensin II, reduced spiral artery remodeling, placental hypoxia, decreased nutrient transport and fetal growth restriction. Taken together, these data strongly implicate AR-mediated testosterone action as an important pathway contributing to clinical manifestation of preeclampsia. This review critically addresses this hypothesis, taking into consideration both clinical and preclinical data.

Reproduction (2018) 156 R155-R167
\end{abstract}

\section{Introduction}

Pregnancy is characterized by major cardiovascular adaptations, including marked decreases in systemic vascular resistance and mean arterial pressure, along with increases in maternal cardiac output and total blood volume (Magness 1998, Thornburg et al. 2000, Chinnathambi et al. 2013a). Studies suggest that pregnancy-enhanced vasodilatory actions allow peripheral vessels to accommodate increases in blood flow and volume (Conrad et al. 1993). Consistently, maternal vascular adaptations are accompanied by blunted vascular contractility (Naden \& Rosenfeld 1981, Magness \& Rosenfeld 1986) and enhanced release of endothelium-derived vasodilatory factors (Kawano \& Mori 1983, Magness et al. 1990, 1996, 2000, Conrad et al. 1993, Sladek et al. 1997, Williams et al. 1997, Gillham et al. 2003, Gokina et al. 2010). Failure of these vascular adaptations during pregnancy are directly related to several maternal/fetal pathologies, such as increased systemic vascular resistance, hypertension, proteinuria, poor placental growth, decreased nutrient transport and low birth weight, all characteristics associated with a diagnosis of preeclampsia (Powe et al. 2011) outlined in Table 1. Despite being a leading contributor of maternal and perinatal morbidity and death worldwide, the etiology and pathogenesis of preeclampsia remain unclear (Roberts et al. 1991, Palei et al. 2013, Salam et al. 2015).

Treatment options for preeclampsia are limited to management of high blood pressure using antihypertensives, such as methyldopa, hydralazine, labetalol and nifedipine (ACOG 2013), as well as magnesium sulfate for prevention of eclamptic seizures (Al Khaja et al. 2014); however, these treatments have limited efficacy, and the only cure is the delivery of the placenta with baby, a totally undesired outcome before late preterm ( $\geq 34$ weeks gestation). While the exact causes of preeclampsia remain unknown, a large body of evidence, supported by preclinical models of preeclampsia, indicates that abnormal placentation early 
Table 1 Diagnostic criteria for preeclampsia in women (ACOG Guidelines 2013).

\begin{tabular}{|c|c|}
\hline Parameter & Diagnostic criteria \\
\hline Blood pressure & $\begin{array}{l}\text { Greater than or equal to } 140 \mathrm{mmHg} \text { systolic or greater than or equal to } 90 \mathrm{mmHg} \\
\text { diastolic on two occasions at least } 4 \mathrm{~h} \text { apart after } 20 \text { weeks of gestation in a woman } \\
\text { with a previously normal blood pressure } \\
\text { OR } \\
\text { Greater than or equal to } 160 \mathrm{mmHg} \text { systolic or greater than or equal to } 110 \mathrm{mmHg} \\
\text { diastolic, hypertension can be confirmed within a short interval (minutes) to facilitate } \\
\text { timely antihypertensive therapy }\end{array}$ \\
\hline Proteinuria & $\begin{array}{l}\text { Greater than or equal to } 300 \mathrm{mg} \text { per } 24 \mathrm{~h} \text { urine collection (or this amount extrapolated } \\
\text { from a timed collection) } \\
\text { OR } \\
\text { Protein/creatinine ratio greater than or equal to } 0.3^{*} \\
\text { Dipstick reading of } 1+\text { (used only if other quantitative methods not available) }\end{array}$ \\
\hline \multicolumn{2}{|c|}{ OR in the absence of proteinuria, new-onset hypertension plus new onset of any of the following: } \\
\hline Thrombocytopenia & Platelet count less than $100,000 /$ microliter \\
\hline Renal insufficiency & $\begin{array}{l}\text { Serum creatinine concentrations greater than } 1.1 \mathrm{mg} / \mathrm{dL} \text { or a doubling of the serum } \\
\text { creatinine concentration in the absence of other renal disease }\end{array}$ \\
\hline Impaired liver function & Elevated blood concentrations of liver transaminases to twice normal concentration \\
\hline \multicolumn{2}{|r|}{ 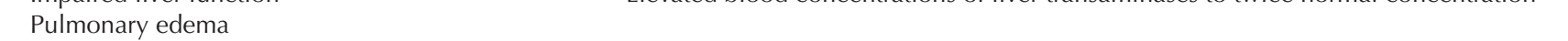 } \\
\hline Cerebral or visual symptoms & \\
\hline
\end{tabular}

*Each measured as $\mathrm{mg} / \mathrm{mL}$.

in pregnancy is an important initial event in the onset of preeclampsia (Roberts \& Redman 1993, Myatt 2002). Such preeclamptic abnormal placentation stimulates the production of anti-angiogenic factors and cytokines, resulting in generalized vascular dysfunction and the clinical manifestation of preeclampsia. In the past several years, dysregulation of steroid hormones, specifically increases in maternal testosterone levels, has emerged as an important endocrinopathy repeatedly associated with clinical manifestations of preeclampsia. In order to develop more effective therapeutic interventions for preeclampsia, it is important to fully understand the role of testosterone in maternal vascular and placental function, as well as blood pressure control, during normal pregnancy and in preeclampsia. This review critically addresses the hypothesis of testosteronemediated pathogenesis of preeclampsia, taking into consideration data from both clinical (human) and preclinical (animal) studies.

\section{Testosterone levels in clinical preeclampsia}

Most studies have investigated the beneficial role of sex steroid hormones, especially estradiol and progesterone, on cardiovascular function during pregnancy in women (Magness 1998). The relationship between testosterone and maternal cardiovascular function, however, is relatively understudied. PubMed search with keywords, 'testosterone, preeclampsia and women', generated 40 publications that were manually screened to identify 14 full-length papers reporting testosterone levels in both preeclampsia and control groups. Twelve of these 14 studies reported elevated plasma levels of testosterone during preeclamptic compared to normotensive (control) pregnancies (Table 2) (Acromite et al. 1999, Serin et al. 2001, Steier et al. 2002, Ficicioglu \& Kutlu 2003,
Miller et al. 2003, Troisi et al. 2003, Atamer et al. 2004, Baksu et al. 2004, Carlsen et al. 2005, GerulewiczVannini et al. 2006, Salamalekis et al. 2006, Ghorashi \& Sheikhvatan 2008, Hsu et al. 2009, Sharifzadeh et al. 2012). These studies report that during late pregnancy, plasma testosterone concentrations range between 100 and $150 \mathrm{ng} / \mathrm{dL}$ and these are 1.5- to 2.4-fold higher in preeclamptic compared to normotensive pregnant women (Fig. 1A). The reported mean unbound or 'free' testosterone level circulating in preeclamptic women is also 1.4- to 3.4-fold higher compared to normotensive pregnancies (Fig. 1B). Some studies also indicate that circulating testosterone levels correlate with the severity of preeclampsia, although this is not a universal finding (Ficicioglu \& Kutlu 2003, Atamer et al. 2004). While there are many androgens, including the relatively bio-ineffective testosterone precursors of dehydroepiandrosterone (DHEA) and androstenedione $\left(\mathrm{A}_{4}\right)$, only circulating levels of testosterone are increased during preeclampsia (Table 2). Preeclamptic hyperandrogenic measures include elevated total testosterone, free testosterone, free androgen index (FAI, total testosterone $\times 100 /$ sex hormone binding globulin) and the testosterone-to-estradiol ratio. Hyperandrogenic pregnant women with polycystic ovary syndrome (PCOS) are at increased risk for preeclampsia (de Vries et al. 1998, Kjerulff et al. 2011, Kamalanathan et al. 2013), and it has been proposed that overproduction of testosterone by the polycystic ovary is the causal factor engaging preeclampsia in PCOS women (Diamant et al. 1982, Sir-Petermann et al. 2002, Codner \& EscobarMorreale 2007). Obesity, and accompanying insulin resistance-induced compensatory hyperinsulinemia, is predictive of preeclampsia (Seely \& Solomon 2003). Insulin stimulates androgen release, including testosterone, from theca cells of normal ovaries 
Table 2 Plasma androgen levels in healthy and preeclamptic pregnant women.

\begin{tabular}{|c|c|c|c|c|}
\hline Reference/Androgen & Normal vs preeclampsia & $\boldsymbol{P}$ & $\begin{array}{l}\% \text { Increase in } \\
\text { preeclampsia }^{\#}\end{array}$ & $\begin{array}{c}\text { Gestational age } \\
\text { (weeks) }\end{array}$ \\
\hline Acromite et al. (1999) & & & & $36-38$ \\
\hline Total TS & 154.5 vs $213.6 \mathrm{ng} / \mathrm{dL}$ & $<0.01$ & 38 & \\
\hline Free TS & 0.3 vs $0.5 \mathrm{ng} / \mathrm{dL}$ & $<0.05$ & 67 & \\
\hline DHEA-S & 175.5 vs $171.0 \mu \mathrm{g} / \mathrm{dL}$ & NS & & \\
\hline Estradiol & 33.8 vs $36.4 \mathrm{~g} / \mathrm{mL}$ & NS & & \\
\hline Salamalekis et al. (2006) & & & & $30-31$ \\
\hline Total TS & 106.3 vs $154.4 \mathrm{ng} / \mathrm{dL}$ & $<0.05$ & 45 & \\
\hline Free TS & 0.21 vs $0.34 \mathrm{ng} / \mathrm{dL}$ & $<0.05$ & 62 & \\
\hline DHEA-S & 76.15 vs $57.62 \mu \mathrm{g} / \mathrm{dL}$ & $>0.05$ & & \\
\hline Androstenedione & 110.5 vs $107.1 \mathrm{ng} / \mathrm{dL}$ & $>0.05$ & & \\
\hline Ghorashi and Sheikhvatan (2008) & & & & $28-39$ \\
\hline Free TS & 0.58 vs $1.97 \mathrm{ng} / \mathrm{dL}$ & 0.001 & 240 & \\
\hline Serin et al. (2001) & & & & $34-39$ \\
\hline Total TS & 24.3 vs $44.1 \mathrm{ng} / \mathrm{dL}$ & $<0.05$ & 81 & \\
\hline Free TS & 0.22 vs $0.44 \mathrm{ng} / \mathrm{dL}$ & $<0.05$ & 100 & \\
\hline DHEA-S & 90.5 vs $162.5 \mu \mathrm{g} / \mathrm{dL}$ & NS & & \\
\hline Androstenedione & 210 vs $220 \mathrm{ng} / \mathrm{dL}$ & NS & & \\
\hline Estradiol & 92.2 vs $73.5 \mathrm{pg} / \mathrm{mL}$ & NS & & \\
\hline Carlsen et al. (2005) & & & & 33 \\
\hline Total TS & 63.4 vs $86.5 \mathrm{ng} / \mathrm{dL}$ & 0.001 & 36 & \\
\hline Free TS index & 0.61 vs 0.83 & 0.012 & 36 & \\
\hline DHEA-S & 102.3 vs $121.5 \mu \mathrm{g} / \mathrm{dL}$ & NS & & \\
\hline Androstenedione & 280 vs 337 ng/dL & NS & & \\
\hline Baksu et al. (2004) & & & & 34 \\
\hline Total TS & 136 vs 257 ng/dL & 0.001 & 89 & \\
\hline Free TS index & 0.31 vs 0.37 & 0.01 & 19 & \\
\hline DHEA-S & 109.1 vs $104.3 \mu \mathrm{g} / \mathrm{dL}$ & NS & & \\
\hline Estradiol & 5830.1 vs $6164.2 \mathrm{pg} / \mathrm{mL}$ & NS & & \\
\hline Steier et al. (2002) & & & & $30-38$ \\
\hline Total TS & 82.1 vs $172.4 \mathrm{ng} / \mathrm{dL}$ & $<0.01$ & 110 & \\
\hline Hsu et al. (2009) & & & & 37 \\
\hline Total TS & 34 vs $52 \mathrm{ng} / \mathrm{dL}$ & $<0.01$ & 53 & \\
\hline Gerulewicz-Vannini et al. (2006) & & & & 37 \\
\hline Total TS & 103.7 vs $152.2 \mathrm{ng} / \mathrm{dL}$ & 0.02 & 47 & \\
\hline Free TS & 0.144 vs $0.594 \mathrm{ng} / \mathrm{dL}$ & 0.002 & 312 & \\
\hline DHEA-S & 70.0 vs $51.1 \mu \mathrm{g} / \mathrm{dL}$ & NS & & \\
\hline Atamer et al. (2004) & & & & $34-35$ \\
\hline Total TS & 29 vs 67 ng/dL & $<0.001$ & 131 & \\
\hline DHEA-S & 108 vs $112 \mu \mathrm{g} / \mathrm{dL}$ & NS & & \\
\hline Androstenedione & 189 vs $158 \mathrm{ng} / \mathrm{dL}$ & NS & & \\
\hline Estradiol & 2927 vs $3572 \mathrm{pg} / \mathrm{mL}$ & NS & & \\
\hline Troisi et al. (2003) & & & & 37 \\
\hline Total TS & 141.9 vs $214.5 \mathrm{ng} / \mathrm{dL}$ & 0.0007 & 51 & \\
\hline Androstenedione & 316.0 vs $506.3 \mathrm{ng} / \mathrm{dL}$ & 0.004 & 60 & \\
\hline Sharifzadeh et al. (2012) & & & & $32-33$ \\
\hline Total TS & 206 vs $370 \mathrm{ng} / \mathrm{dL}$ & $<0.01$ & 80 & \\
\hline Free TS & 0.074 vs 0.128 & $<0.01$ & 73 & \\
\hline DHEA-S & 51 vs $75 \mu \mathrm{g} / \mathrm{dL}$ & NS & & \\
\hline Miller et al. (2003) & & & & 35 \\
\hline Total TS & 206 vs 147 ng/dL & NS & & \\
\hline Free TS index & 2.03 vs 1.50 & NS & & \\
\hline DHEA-S & 75 vs $75 \mu \mathrm{g} / \mathrm{dL}$ & NS & & \\
\hline Estradiol & 18,536 vs $9619 \mathrm{pg} / \mathrm{mL}$ & NS & & \\
\hline Ficicioglu and Kutlu (2003) & & & & $34-35$ \\
\hline Total TS & 218 vs 209 ng/dL & NS & & \\
\hline Free TS index & 4.16 vs 5.24 & NS & & \\
\hline DHEA-S & $104 \mathrm{vs} 77 \mu \mathrm{g} / \mathrm{dL}$ & $<0.05$ & & \\
\hline Estradiol & 21,880 vs $21,370 \mathrm{pg} / \mathrm{mL}$ & NS & & \\
\hline
\end{tabular}

All these studies used immunoassays (ELISA and RIA) to measure TS levels. This raises concern regarding assay sensitivity and the specificity because of risk of cross-reactivity between steroids and their multiple placental metabolites. Recently, liquid chromatography tandem mass spectrometry (LC-MS/MS) has been suggested as the new 'gold standard' method for measurement of TS levels. This recommendation is more geared towards situations in which measurements of TS are below detectable levels (such as in hypogonadal men, women, children etc.) or in species for which no specific antibodies are available (such as sheep). Recent studies that compared the predictive values of TS levels measured by LC-MS/MS and immunoassay showed no significant difference between the two analytical methods (Czeloth et al. 2017, Mitchell 2012). The TS levels reported in the studies cited here may be appropriate for two reasons. First, the TS levels in pregnant women are within detectable range, and second, the objective is to detect relative change in preeclamptic group compared to controls.

$\# \%$ increase is calculated as $100 \times$ (preeclampsia - normal)/normal.

TS, testosterone; NS, not significant. 

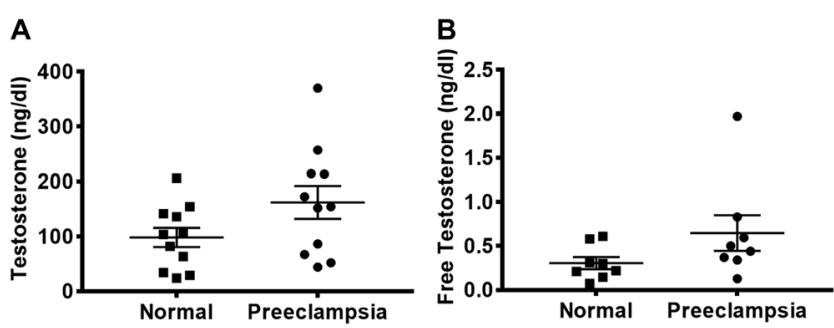

Figure 1 Mean higher total (A) and free testosterone (B) levels reported in preeclamptic patients compared normotensive controls in published studies cited in Table 1. Each point represents a single published study.

(Franks et al. 1999), and thus, the exaggerated hyperinsulinemia of obesity during preeclamptic gestation (Kaaja et al. 1995, Lorentzen et al. 1998) likely contributes to increased maternal testosterone levels (Andersen et al. 1995, Pasquali et al. 2000, SuttonTyrrell et al. 2010). Since both obesity, hyperinsulinemia and preeclampsia are more prevalent among hyperandrogenic pregnant women with PCOS than in pregnant women without PCOS (Lonnebotn et al. 2018), obesity-enhanced maternal testosterone levels may contribute to PCOS-associated preeclampsia.

Ethnicity has also been implicated in contributing hyperandrogenism-related preeclampsia. Pregnant African-American women exhibit high maternal testosterone levels (120-130\%), including elevated fetal cord blood testosterone levels at term (Henderson et al. 1988, Potischman et al. 2005, Rohrmann et al. 2009, Agurs-Collins et al. 2012) and are at increased risk for developing preeclampsia (Samadi et al. 2001, lavazzo \& Vitoratos 2010). In addition, plasma testosterone

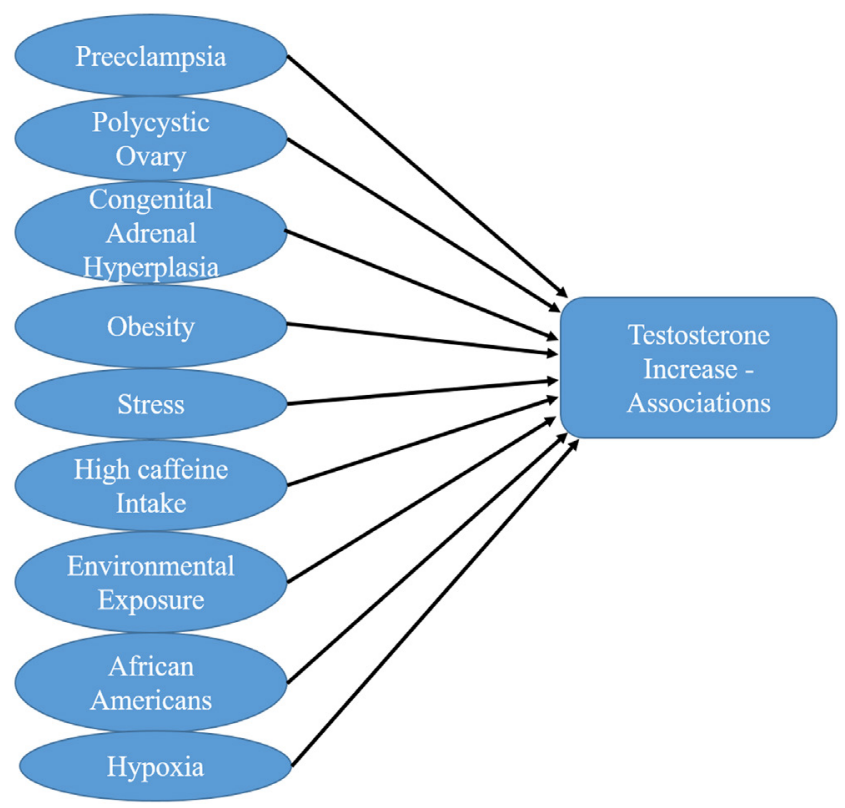

Figure 2 Possible associations for testosterone increase in females and pregnancy. levels are increased during pregnancy in a variety of situations (Fig. 2), including classical congenital adrenal hyperplasia (Warmann et al. 2000, Mains et al. 2007), high caffeine intake (Ferrini \& Barrett-Connor 1998, Svartberg et al. 2003) and stress (Sarkar et al. 2007, 2008), all of which are known risk factors for preeclampsia. Furthermore, pregnant women are inadvertently exposed to elevated testosterone levels via environmental pollutants and anabolic steroids (endocrine disruptors). High androgenic activity is reported in water from craft pulp and paper mills, as well as concentrated animal feed operations in the United States and Europe (Parks et al. 2001, Orlando et al. 2004). Reports have shown that an androgenic growth promoter used in beef cattle, trenbolone, has a half-life of greater than 260 days in animal by-products (Schiffer et al. 2001, Hotchkiss \& Nelson 2007).

The degree of hyperandrogenism in preeclamptic women varies depending on the sex of their fetus. Preeclamptic women bearing sons exhibit higher testosterone levels than preeclamptic women bearing daughters (Steier et al. 2002), contributing to the notion that a male fetus and its placenta contribute additional amounts of testosterone to the maternal circulation (Sathishkumar et al. 2012). Such pregnant women bearing male fetuses are at increased risk for developing preeclampsia and placental dysfunction (Stark et al. 2006, Murji et al. 2012, Sykes et al. 2014, Li et al. 2018). Furthermore, daughters experiencing a preeclamptic gestation demonstrate higher circulating testosterone levels when they reach puberty (Alsnes et al. 2016). Such female offspring are at increased risk of developing hypertension and cardiovascular disease as adults (King et al. 2007, Sathishkumar et al. 2011c, Chinnathambi et al. 2012, 2013b, Vyas et al. 2016), and possibly preeclampsia and other pregnancy-related complications. High testosterone levels persist for at least 17 years in women with a documented history of preeclampsia (Laivuori et al. 1998). These studies thus provide consistent circumstantial evidence linking increased testosterone levels with preeclampsia.

The origin of the increased testosterone levels during preeclampsia remain uncertain. Studies suggest a placental contribution (Steier et al. 2002, Dokras et al. 2003). The human placenta, however, lacks the key androgen biosynthetic enzymes, $17 \beta$-hydroxylase and 17,20-desmolase (Christensen 1974). It nevertheless expresses 3 $\beta$-hydroxysteroid dehydrogenase type 1 (HSD3B1) (Mason et al. 1993), endowing a ready ability to convert DHEA into $\mathrm{A}_{4}$, as well as the estrogen-preferring 17 $\beta$-hydroxysteroid dehydrogenase type 1 (HSD17B1) (Takeyama et al. 1998), endowing a weak ability to synthesize testosterone from $\mathrm{A}_{4}$. After mid-gestation, both maternal and fetal adrenals equally contribute as the major sources of $\mathrm{C} 19$ steroids for placental androgen biosynthesis (Turnipseed et al. 1976, Kowalczyk et al. 1998). The human fetal adrenal cortex includes a fetal 


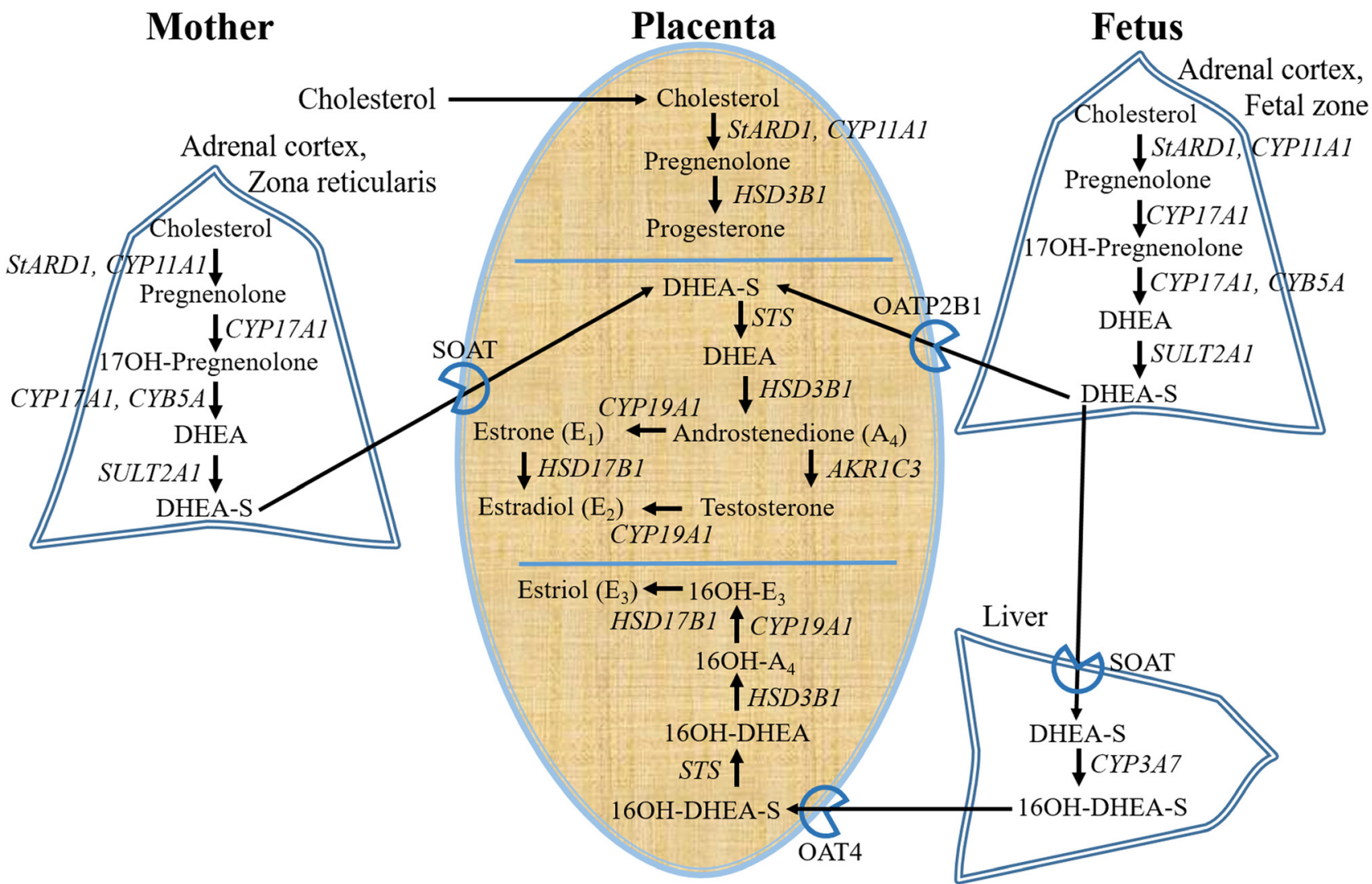

Figure 3 Pathway of biosynthesis and metabolism of testosterone, primary estrogens and progesterone during pregnancy. StARD1, steroidogenic acute regulatory protein; CYP11A1, cholesterol side-chain cleavage enzyme; HSD3B1, 3beta-hydroxysteroid dehydrogenase; CYP17A1,

$17 \alpha$-hydroxylase/17,20-lyase; CYB5A, cytochrome b5; SULT2A1, sulfotransferase; STS, steroid sulfatase; AKR1C3, aldo-keto reductase type 1C3; HSD17B1, hydroxysteroid 17-beta dehydrogenase 1; CYP19A1, aromatase - cell membrane-located uptake carriers of DHEAS; SOAT, sodium dependent organic anion transporter; OATP2B1 and OAT4, organic anion transporters.

zone, expressing StARD1, CYP11A1, CYP17A1 and SULT2A1, essential for production of DHEA and DHEAS sulfate (DHEA-S), analogous to the maternal zona reticularis, the innermost zone of the maternal adrenal cortex (Fig. 3). After membrane uptake carrier transport into placental syncytiotrophoblast cells, sulfonated testosterone precursors (i.e. DHEA-S) are desulfonated by the enzyme sulfatase (STS) to yield DHEA. Placental steroidogenic enzymes (Fig. 3) then convert DHEA to $\mathrm{A}_{4}$ (HSD3B1), and $\mathrm{A}_{4}$ to testosterone (ARK1C3). Accompanying high levels of placental aromatase expression (Mason et al. 1993) ensure ready conversion of placental androgens, including testosterone, into non-androgenic, estrogenic metabolites (Gant et al. 1971, Buster et al. 1979, Dokras et al. 2003), including estrone, estradiol and their catechol and methoxy metabolites, some of which display placental bioactivity rivaling that of $\mathrm{E}_{2}$ (Jobe et al. 2011, Landeros et al. 2018).

The finding that there are no statistically significant differences regarding circulating maternal levels of DHEA-S and $\mathrm{A}_{4}$ between control and preeclamptic pregnancies implies that there is no contribution of adrenal steroids to the hyperandrogenism of preeclampsia. Placental aromatase mRNA and protein expression, however, is decreased in the preeclamptic placenta, diminishing metabolism of $\mathrm{A}_{4}$ and testosterone into estrogenic metabolites, and tipping the equilibrium between estrogens and androgens in favor of androgens (Sathishkumar et al. 2012, Perez-Sepulveda et al. 2015). Hepatic conjugation, and thus inactivation, of estrogens also appears diminished during preeclamptic gestations. Maternal circulating levels of unconjugated estrogens, however, remain unchanged from those in normotensive pregnant women (Rosing \& Carlstrom 1984). Studies show that testosterone, alone, diminishes aromatase mRNA expression in human trophoblast cells through a miR-22-mediated mechanism (Shao et al. 2017). Other factors, tumor necrosis factor alpha (Lau et al. 2013) and lipid radicals (Mori et al. 2014), which are increased during preeclampsia downregulate aromatase (Milczarek et al. 2008, Diaz et al. 2009). In addition, hypoxia (which mirrors the actual conditions of the placenta in the context of preeclampsia) also downregulates placental aromatase (Jiang et al. 2000, Perez-Sepulveda et al. 2015, Yu et al. 2015). It would be interesting to assess whether compromised expression 
of aromatase also exists in tissues and organs other than placenta during preeclamptic gestation. A recent study also indicated that overexpression of CYP11A1 mRNA (commonly referred as cholesterol side-chain cleavage enzyme that catalyzes the first steps of steroidogenesis) in human trophoblast cells induces increased testosterone production and preeclampsialike placental dysfunction that could be reversed with flutamide, an androgen receptor antagonist (Pan et al. 2017). Taken together, these findings support the notion that increased testosterone during preeclamptic pregnancies may be of placental origin, although other sources cannot be excluded.

\section{Testosterone and maternal blood pressure and uterine artery blood flow}

In healthy women experiencing no complications during pregnancy, arterial pressure is stable during the early part of first trimester and then gradually decreases, reaching a nadir during the second trimester (Magness 1998, Bosio et al. 1999). Lack of this pregnancy-related decrease in blood pressure indicates a failure in normal cardiovascular adaptation and is considered to be a cardinal feature of preeclampsia (Ishikuro et al. 2012). Several independent investigators have demonstrated, through human and animal studies, the association of androgens, especially testosterone, with hypertension (Nakao et al. 1981, Reckelhoff et al. 1998, Gonzales et al. 2004, 2005, Park et al. 2004, Chen et al. 2007, Yanes et al. 2009, Makinen et al. 2011). Testosterone levels correlate positively with systolic blood pressure and diastolic blood pressure during and after preeclampsia (Laivuori et al. 1998, Serin et al. 2001, Carlsen \& Heimstad 2012). Experimentally induced increases in maternal testosterone levels during pregnancy in rats, at concentrations that mimic testosterone levels found in human preeclamptic pregnancies, induce increases in systemic arterial pressure (Chinnathambi et al. 2013a, 2014b, Fornes et al. 2016), implying a causal role for testosterone in raising blood pressure during gestation. The exact mechanism by which testosterone mediates an increase in maternal blood pressure during pregnancy is not clear, but accumulating evidence indicates that testosterone increases vascular reactivity, activating the renin-angiotensin system and altering eicosanoid metabolism, thus favoring an increase in the thromboxane $\mathrm{A} 2$ to prostacyclin $(\mathrm{PGI} 2)$ ratio and causing platelet aggregation in ways that are strikingly similar to those reported in preeclampsia (Acromite et al. 1999). Our unpublished observations also show that elevating rat maternal testosterone levels during pregnancy induce renal hypertrophy and proteinuria, a hallmark feature of preeclampsia (Sathishkumar et al. 2011a). Treatment with a selective angiotensin type 1 receptor $\left(A T_{1} R\right)$ antagonist, losartan, markedly attenuated the hypertension induced by testosterone in the pregnant rats (Chinnathambi et al. 2014b). These findings suggest that $\mathrm{AT}_{1} \mathrm{R}$ activation contributes, at least in part, to the testosterone-induced increase in blood pressure in rat pregnancies.

In addition to adjustments in systemic vasculature, the uteroplacental circulation normally adapts to maintain a low vascular tone to accommodate a more than 20-fold increase in uterine blood flow near-term (Rosenfeld et al. 1974, Magness 1998, Osol \& Mandala 2009). Studies in hyperandrogenic women with PCOS have shown that their high maternal testosterone levels are associated with increased uterine artery resistance index and reduced blood flow (Palomba et al. 2010, 2012). Experimentally induced increase in maternal testosterone levels in pregnant rats show significantly reduced uterine arterial blood flow by $40 \%$ (measured using transcutaneous micro ultrasound) (Gopalakrishnan et al. 2016). In addition, elevated testosterone decreases uterine arterial diameter and increases resistance and pulsatile index (Gopalakrishnan et al. 2016). These findings suggest that the mechanisms controlling blood pressure and uterine artery hemodynamics during pregnancy are perturbed by elevated maternal testosterone levels. Primary estrogens, estrone, estradiol- $17 \beta$ and estriol play an important role in maintaining uterine blood flow and blunting vascular responses during pregnancy (Albrecht \& Pepe 1990, Magness 1998). Jobe et al. (2013) elegantly demonstrated that these primary estrogens, and the majority of their catechol and methoxy metabolites, including those with demonstrable placental bioactivity (Jobe et al. 2011, Landeros et al. 2018), are reduced in preeclampsia (Jobe et al. 2013). The lower levels of primary estrogens, together with the reduced expression of placental aromatase could induce precursor steroid hormone accumulation, causing C19 steroids, especially testosterone, to be elevated. It is unclear if elevated testosterone acts independently or if it synergies with reduced downstream C18 estrogens to cause preeclampsia progression. Progesterone levels, however, are reported to be normal (Rosing \& Carlstrom 1984, Bussen et al. 1998, Hertig et al. 2010), decreased (Acikgoz et al. 2013, Wan et al. 2018) or increased (Tamimi et al. 2003, Metz et al. 2014) in preeclampsia. Further studies will be needed to clarify whether there is hitherto unrecognized relationship between progesterone and testosterone, and if they work in concert in preeclampsia pathogenesis.

\section{Testosterone-induced mechanisms of vascular dysfunction during pregnancy}

\section{Effects on endothelium-dependent relaxation}

In humans, normal maternal vascular adaptations are accompanied by enhanced release of three major endothelium-derived vasodilatory factors including nitric oxide (NO) (Conrad et al. 1993, Sladek et al. 1997, 
Williams et al. 1997), PGI2 (Kawano \& Mori 1983, Magness et al. 1990, 1996, 2000) and endotheliumderived hyperpolarizing factor (EDHF) (Gillham et al. 2003, Gokina et al. 2010). This is accompanied with concomitant pregnancy-induced increases in mRNA and protein expression of endothelial NO synthase (eNOS) (Sladek et al. 1997, Williams et al. 1997, Nelson et al. 2000, Magness et al. 2001), endothelial prostaglandin-I synthase (PGIS) (Bird et al. 2000, Magness et al. 2000) and EDHF activity (Gokina et al. 2010). In the systemic circulation, the principal endothelium-dependent vasodilators are $\mathrm{NO}$ and EDHF (Chinnathambi et al. 2013a). In the uterine arteries, in addition to $\mathrm{NO}$ and $\mathrm{EDHF}, \mathrm{PGI} 2$ also plays a role in mediating vascular relaxation (Cooke \& Davidge 2003). Elevated testosterone is shown to inhibit acetylcholineinduced relaxation of rat mesenteric and uterine arteries suggesting that elevated testosterone impairs endothelium-dependent relaxation. Specifically, the NO-mediated vasodilation was significantly decreased in mesenteric and uterine arteries in a pregnant rat model of elevated maternal testosterone (Chinnathambi et al. 2013a, 2014a). This testosterone-induced decrease in NO-mediated arterial relaxation was found not related to decreased vascular smooth muscle sensitivity to NO, as relaxation of arterial rings to sodium nitroprusside, an exogenous NO donor, was not affected (Chinnathambi et al. 2013a, 2014a). These findings indicate that testosterone likely alters synthesis/release of NO. Consistently, studies in rats have shown that testosterone decreases plasma levels of $\mathrm{NO}_{x}$ (marker of $\mathrm{NO}$ production) with decreases in eNOS protein expression in uterine arteries (Chinnathambi et al. 2014a) and eNOS activity (decreased phosphorylation at excitatory Ser ${ }^{1177}$ site and increased phosphorylation at inhibitory $\mathrm{Thr}^{495}$ site) in mesenteric arteries (Chinnathambi et al. 2013a). The effect of testosterone in rat uterine arteries appears to be more profound than that in mesenteric arteries as in addition to decreasing $\mathrm{NO}$ pathway, it also compromises the EDHF- and $\mathrm{PGI}_{2}$-mediated relaxation by decreasing expression of small conductance calciumactivated channel-3 and PGI2 receptor, respectively (Chinnathambi et al. 2014a). Taken together, these results suggest that elevated testosterone during pregnancy may specifically impair the NO-mediated relaxation in systemic (mesenteric) vessels, while it compromises all three major vasodilatory pathways in reproductive (uterine) vessels.

\section{Effects on vascular smooth muscle contractile response}

Systemic and uterine vasculature are refractory to vasoconstrictions during pregnancy. In contrast, enhanced contractile responses to vasoconstrictors is a characteristic feature of preeclampsia (Naden \& Rosenfeld 1981, Magness \& Rosenfeld 1986, Benoit et al. 2007, Stanhewicz et al. 2017). Elevated testosterone during pregnancy is shown to enhance contractile responses to many vasoconstrictors in endothelium-intact vessels, but in endothelium-denuded vessels, there is enhanced contractile response specific to angiotensin II in rat mesenteric (Chinnathambi et al. 2014b) and uterine arteries (Chinnathambi et al. 2014a). These enhanced responses observed in rat endothelium-denuded vessels indicate that enhanced arterial sensitivity is primarily because of increased angiotensin II-induced contractions, per se, rather than the loss of the endotheliummediated relaxation component (Chinnathambi et al. 2014a). Since elevated testosterone does not alter the vasomotor response to other potent constrictors, such as $\mathrm{K}^{+}$depolarization, thromboxane agonist U46619 and phenylephrine in endothelium-denuded vessels (Chinnathambi et al. 2014a,b), it appears that testosterone has a selective effect in enhancing vascular smooth muscle response to angiotensin II. It is possible that testosteronemediated vascular smooth muscle dysfunction occurs at the agonist-specific receptor level rather than at common intracellular signaling pathways. Consistently, studies show that gestational elevation in testosterone levels causes selective upregulation of vasocontractile $\mathrm{AT}_{1}$ receptor and downregulation of vasodilatory $\mathrm{AT}_{2}$ receptor in mesenteric and uterine arteries implying that increased $\mathrm{AT}_{1} / \mathrm{AT}_{2}$ receptor ratio may play an underlying role in testosterone-induced exaggerated vasoconstriction to angiotensin II (Chinnathambi et al. 2014a,b).

\section{Testosterone on placental development and function}

The progenitor cytotrophoblast cell is the stem cell of the placenta. These cells proliferate throughout gestation, differentiating along two pathways to form either villous cytotrophoblast, which ultimately can become syncytiotrophoblasts (outer cellular layer) or extravillous cytotrophoblasts (inner cellular layer). Syncytiotrophoblast is a specialized epithelium that has several functions, including transport of gases, nutrients and waste products and synthesis of peptide and steroid hormones that regulate placental, fetal and maternal systems. Extravillous trophoblasts have a proliferative component and an invasive component. There is also a migratory extravillous trophoblast, which is neither invasive nor proliferative. AR is present in syncytiotrophoblasts and in the decidua during the first trimester of human gestation (Horie et al. 1992). The expression of $A R$ in human preeclamptic placentae is considerably higher than its expression in healthy placentae from uncomplicated pregnancies (Hsu et al. 2009, Sathishkumar et al. 2012). Also, genetic polymorphisms in the AR gene are associated with increased risk of preeclampsia (Limetal.2011). Ratmodels show that experimentally elevated maternal testosterone levels during pregnancy induce a reduction in placental size and weight (Sathishkumar et al. 2011b, Sun et al. 
2012). The reason for smaller placenta in testosteroneexposed dams is not known, but may involve increased apoptosis or decreased proliferation (Ling et al. 2002). Pan et al. (2017) revealed a critical role for testosterone in human trophoblast invasion and demonstrated that flutamide, an AR antagonist, could rescue testosteroneinduced reduction in invasion (Pan et al. 2017). It is possible that testosterone-induced autophagy (human) (Pan et al. 2017), reduced invasion (human) (Pan et al. 2017) or advanced placental differentiation (sheep) (Veiga-Lopez et al. 2011), may all contribute to such alterations in placental weight/morphology.

Vasculogenesis and angiogenesis are critical processes that lead to the formation of the placental vascular network necessary for optimal uteroplacental circulation (Huppertz \& Peeters 2005, Arroyo \& Winn 2008). Testosterone, however, downregulates the expression of genes related to vascular development and angiogenesis (Ccr3, Stra6, Dhcr7, Arid1a, Ptpri, Col1a2, Lef1, Col1a 1 and $\mathrm{Mmp2}$ ) in the rat placenta (Gopalakrishnan et al. 2016). Along with this antivasculogenic gene expression profile, testosterone also decreases the radial and spiral artery diameters and inhibits branching angiogenesis (Gopalakrishnan et al. 2016). One of the important functions of the placenta is to promote nutrient transport to the fetus. Elevated testosterone is shown to decrease placental amino acid transport to rat fetuses (Sathishkumar et al. 2011b). This reduction in amino acid transport is related to reduced expression of the system A amino acid transporters (slc38a2/Snat 2) in the rat placenta (Sathishkumar et al. 2011b). Testosterone also decreases placental oxygenation with associated increase in hypoxia-inducible factor $1 \alpha$ and hypoxia responsive genes, presumable due to compromised placental vascularization (Gopalakrishnan et al. 2016). In addition to placental compromise, the fetuses of testosterone -exposed pregnant rats also receive less oxygen and are hypoxic (Gopalakrishnan et al. 2016). Elevated testosterone, however, does not alter glucose transport across the rat placenta (Sathishkumar et al. 2011b). Thus, testosterone increases during pregnancy alter placental structure and function leading to decreases in amino acid and oxygen availability to the fetus.

\section{Testosterone effects on fetal growth}

Studies have shown that elevated maternal testosterone levels are associated with reduced birth weights in certain human populations (Sir-Petermann et al. 2005, Carlsen et al. 2006, Mehrabian \& Kelishadi 2012), rats (Sun et al. 2012, Fornes et al. 2016), sheep (Manikkam et al. 2004, Steckler et al. 2005, Recabarren et al. 2008, Beckett et al. 2014) and marmoset monkeys (Smith et al. 2010), but not in rhesus monkeys (Abbott et al. 2010) and not in human populations of non-Spanish descent (Abbott et al. 2016). In rhesus monkeys, testosterone was experimentally increased during early-to-mid-gestation, 2 months prior to parturition, hence, it is possible that initial fetal growth restriction is masked by subsequent in utero catchup growth. Female infant monkeys, rats and sheep exposed to such gestational testosterone excess, however, exhibit accelerated body weight gain 2 months following parturition (Manikkam et al. 2004, Abbott et al. 2010, Sathishkumar et al. 2011c) and demonstrate increased abdominal adiposity and onset of type 2 diabetes and hypertension in adulthood (Chinnathambi et al. 2012, 2013b, Abbott et al. 2016). Testosterone is a lipophilic hormone and can diffuse across tissues, including placenta (Dell'Acqua et al. 1966, Meulenberg \& Hofman 1991, Wang et al. 2005); however, whether fetal growth restriction induced by testosterone is the result of a direct effect on the fetus, or is secondary to decreased uterine blood flow or compromised placental function, remains to be resolved.

\section{Conclusions}

Several studies show that circulating levels of testosterone are two- to three-fold higher in preeclamptic pregnancies

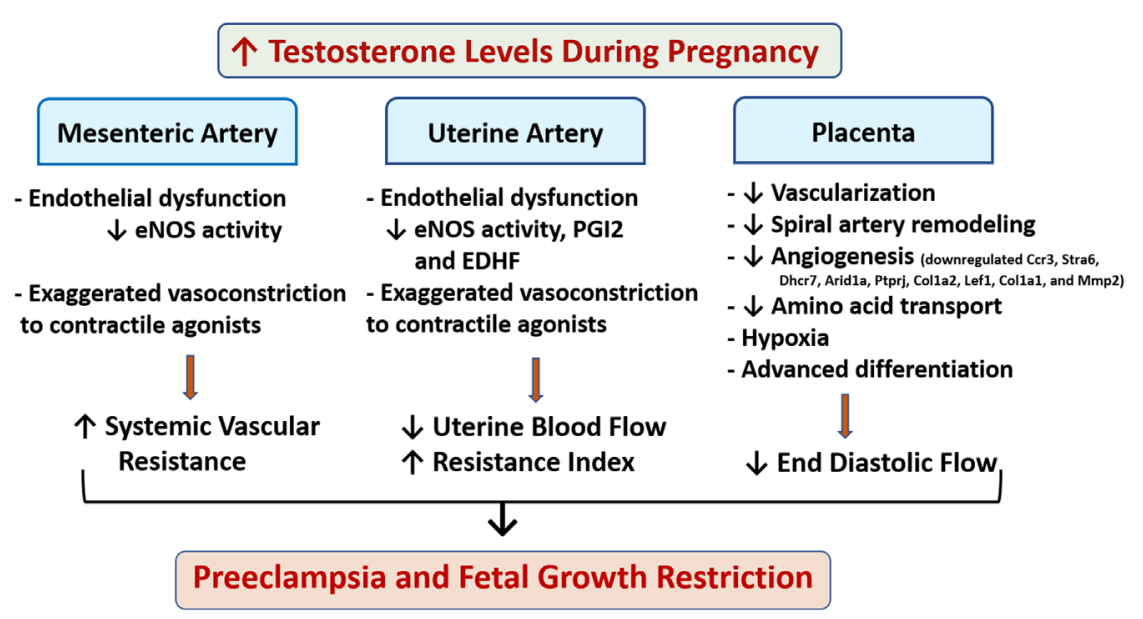

Figure 4 Unifying model depicting the central role of testosterone in preeclampsia. Increased testosterone level causes systemic, uterine and placental vascular dysfunction leading to increased blood pressure, decreased uterine artery blood flow and placental insufficiency, which may contribute to fetal growth restriction. 
compared to those of healthy women experiencing uncomplicated pregnancies. Elevated testosterone in pregnant rats results in significantly increased arterial pressure and decreased uterine arterial hemodynamics. Testosterone, in pregnant rats, also causes endothelial dysfunction and exaggerated vasoconstriction to contractile agonists and dysregulates renin-angiotensin system with exaggerated vascular smooth muscle sensitivity to angiotensin II. In addition, testosterone compromises rat placenta vascularization and nutrient transport leading to placental hypoxia and fetal growth restriction. It is therefore possible that some of the vascular and placental effects observed during preeclampsia may indeed be testosterone mediated (Fig. 4). Therefore, strategies that (1) diminish excessive testosterone action in the cardiovascular and placental system and (2) identify the cause(s) of testosterone elevations during pregnancy, could have important therapeutic potential in treatment of pregnancies complicated by vascular dysfunction and fetal growth restriction.

\section{Declaration of interest}

The authors declare that there is no conflict of interest that could be perceived as prejudicing the impartiality of this review.

\section{Funding}

Financial support from the National Institute of Health (NIH) through grants HD069750, HL119869 and HL134779 (PI: S K), as well as HD044405 (PI: A Dunaif) and HD028934 (PI: J Marshall) supporting DHA, is greatly appreciated.

\section{References}

Abbott DH, Bruns CR, Barnett DK, Dunaif A, Goodfriend TL, Dumesic DA \& Tarantal AF 2010 Experimentally induced gestational androgen excess disrupts glucoregulation in rhesus monkey dams and their female offspring. American Journal of Physiology: Endocrinology and Metabolism 299 E741-E751. (https://doi.org/10.1152/ajpendo.00058.2010)

Abbott DH, Levine JE \& Dumesic DA 2016 Translational insight into polycystic ovary syndrome (PCOS) from female monkeys with PCOSlike traits. Current Pharmaceutical Design 22 5625-5633. (https://doi.or $\mathrm{g} / 10.2174 / 1381612822666160715133437)$

Acikgoz S, Bayar UO, Can M, Guven B, Mungan G, Dogan S \& Sumbuloglu V 2013 Levels of oxidized LDL, estrogens, and progesterone in placenta tissues and serum paraoxonase activity in preeclampsia. Mediators of Inflammation 2013 862982. (https://doi.org/10.1155/2013/862982)

ACOG, Task Force on Hypertension in Pregnancy 2013 Hypertension in pregnancy. Report of the American College of Obstetricians and Gynecologists' Task Force on Hypertension in Pregnancy. Obstetrics and Gynecology 122 1122-1131. (https://doi.org/10.1097/01. AOG.0000437382.03963.88)

Acromite MT, Mantzoros CS, Leach RE, Hurwitz J \& Dorey LG 1999 Androgens in preeclampsia. American Journal of Obstetrics and Gynecology 180 60-63. (https://doi.org/10.1016/S0002-9378(99)70150-X)

Agurs-Collins T, Rohrmann S, Sutcliffe C, Bienstock JL, Monsegue D, Akereyeni F, Bradwin G, Rifai N, Pollak MN \& Platz EA 2012 Racial variation in umbilical cord blood sex steroid hormones and the insulinlike growth factor axis in African-American and white female neonates. Cancer Causes and Control 23 445-454. (https://doi.org/10.1007/ s10552-011-9893-6)
Al Khaja KA, Sequeira RP, Alkhaja AK \& Damanhori AH 2014 Drug treatment of hypertension in pregnancy: a critical review of adult guideline recommendations. Journal of Hypertension 32 454-463. (https://doi.org/10.1097/HJH.0000000000000069)

Albrecht ED \& Pepe GJ 1990 Placental steroid hormone biosynthesis in primate pregnancy. Endocrine Reviews 11 124-150. (https://doi. org/10.1210/edrv-11-1-124)

Alsnes IV, Janszky I, Asvold BO, Okland I, Forman MR \& Vatten LJ 2016 Maternal preeclampsia and androgens in the offspring around puberty: a follow-up study. PLoS ONE 11 e0167714. (https://doi.org/10.1371/ journal.pone.0167714)

Andersen P, Seljeflot I, Abdelnoor M, Arnesen H, Dale PO, Lovik A \& Birkeland K 1995 Increased insulin sensitivity and fibrinolytic capacity after dietary intervention in obese women with polycystic ovary syndrome. Metabolism: Clinical and Experimental 44 611-616. (https:// doi.org/10.1016/0026-0495(95)90118-3)

Arroyo JA \& Winn VD 2008 Vasculogenesis and angiogenesis in the IUGR placenta. Seminars in Perinatology 32 172-177. (https://doi. org/10.1053/j.semperi.2008.02.006)

Atamer Y, Erden AC, Demir B, Kocyigit Y \& Atamer A 2004 The relationship between plasma levels of leptin and androgen in healthy and preeclamptic pregnant women. Acta Obstetricia et Gynecologica Scandinavica 83 425-430. (https://doi.org/10.1111/j.0001-6349.2004.00276.x)

Baksu A, Gurarslan H \& Goker N 2004 Androgen levels in pre-eclamptic pregnant women. International Journal of Gynecology and Obstetrics $\mathbf{8 4}$ 247-248. (https://doi.org/10.1016/S0020-7292(03)00318-7)

Beckett EM, Astapova O, Steckler TL, Veiga-Lopez A \& Padmanabhan V 2014 Developmental programing: impact of testosterone on placental differentiation. Reproduction 148 199-209. (https://doi.org/10.1530/ REP-14-0055)

Benoit C, Zavecz J \& Wang Y 2007 Vasoreactivity of chorionic plate arteries in response to vasoconstrictors produced by preeclamptic placentas. Placenta 28 498-504. (https://doi.org/10.1016/j.placenta. 2006.09.002)

Bird IM, Sullivan JA, Di T, Cale JM, Zhang L, Zheng J \& Magness RR 2000 Pregnancy-dependent changes in cell signaling underlie changes in differential control of vasodilator production in uterine artery endothelial cells. Endocrinology 141 1107-1117. (https://doi.org/10.1210/ endo.141.3.7367)

Bosio PM, McKenna PJ, Conroy R \& O'Herlihy C 1999 Maternal central hemodynamics in hypertensive disorders of pregnancy. Obstetrics and Gynecology 94 978-984. (https://doi.org/10.1016/s00297844(99)00430-5)

Bussen SS, Sutterlin MW \& Steck T 1998 Plasma renin activity and aldosterone serum concentration are decreased in severe preeclampsia but not in the HELLP-syndrome. Acta Obstetricia et Gynecologica Scandinavica 77 609-613. (https://doi.org/10.1034/j.16000412.1998.770606.x)

Buster JE, Chang RJ, Preston DL, Elashoff RM, Cousins LM, Abraham GE, Hobel CJ \& Marshall JR 1979 Interrelationships of circulating maternal steroid concentrations in third trimester pregnancies. II. C18 and C19 steroids: estradiol, estriol, dehydroepiandrosterone, dehydroepiandrosterone sulfate, delta 5-androstenediol, delta 4-androstenedione, testosterone, and dihydrotestosterone. Journal of Clinical Endocrinology and Metabolism 48 139-142. (https://doi. org/10.1210/jcem-48-1-139)

Carlsen SM \& Heimstad R 2012 Androgen levels are associated with blood pressure in pregnant women after term. Acta Obstetricia et Gynecologica Scandinavica 91 232-236. (https://doi.org/10.1111/ j.1600-0412.2011.01280.x)

Carlsen SM, Romundstad P \& Jacobsen G 2005 Early second-trimester maternal hyperandrogenemia and subsequent preeclampsia: a prospective study. Acta Obstetricia et Gynecologica Scandinavica $\mathbf{8 4}$ 117-121. (https://doi.org/10.1111/j.0001-6349.2005.00493.x)

Carlsen SM, Jacobsen G \& Romundstad P 2006 Maternal testosterone levels during pregnancy are associated with offspring size at birth. European Journal of Endocrinology 155 365-370. (https://doi.org/10.1530/ eje.1.02200)

Chen MJ, Yang WS, Yang JH, Chen CL, Ho HN \& Yang YS 2007 Relationship between androgen levels and blood pressure in young women with polycystic ovary syndrome. Hypertension 49 1442-1447. (https://doi. org/10.1161/HYPERTENSIONAHA.106.083972) 
Chinnathambi V, Balakrishnan M, Yallampalli C \& Sathishkumar K 2012 Prenatal testosterone exposure leads to hypertension that is gonadal hormone-dependent in adult rat male and female offspring. Biology of Reproduction 86 131-137. (https://doi.org/10.1095/ biolreprod.111.097550)

Chinnathambi V, Balakrishnan M, Ramadoss J, Yallampalli C \& Sathishkumar K 2013a Testosterone alters maternal vascular adaptations: role of the endothelial NO system. Hypertension 61 647-654. (https:// doi.org/10.1161/HYPERTENSIONAHA.111.00486)

Chinnathambi V, Yallampalli C \& Sathishkumar K 2013b Prenatal testosterone induces sex-specific dysfunction in endotheliumdependent relaxation pathways in adult male and female rats. Biology of Reproduction 89 97. (https://doi.org/10.1095/biolreprod.113.111542)

Chinnathambi V, Blesson CS, Vincent KL, Saade GR, Hankins GD, Yallampalli C \& Sathishkumar K 2014a Elevated testosterone levels during rat pregnancy cause hypersensitivity to angiotensin II and attenuation of endothelium-dependent vasodilation in uterine arteries. Hypertension 64 405-414. (https://doi.org/10.1161/ HYPERTENSIONAHA.114.03283)

Chinnathambi V, More AS, Hankins GD, Yallampalli C \& Sathishkumar K $2014 b$ Gestational exposure to elevated testosterone levels induces hypertension via heightened vascular angiotensin II type 1 receptor signaling in rats. Biology of Reproduction 91 6. (https://doi.org/10.1095/ biolreprod.114.118968)

Christensen A 1974 Hormone and enzyme assays in pregnancy. I. Studies on the placental and the tissue cystine-aminopeptidase activity in peripheral plasma from non-pregnant and pregnant women, and in plasma from the umbilical cord. Acta Endocrinology 76 189-200.

Codner E \& Escobar-Morreale HF 2007 Clinical review: hyperandrogenism and polycystic ovary syndrome in women with type 1 diabetes mellitus. Journal of Clinical Endocrinology and Metabolism 92 1209-1216. (https://doi.org/10.1210/jc.2006-2641)

Conrad KP, Joffe GM, Kruszyna H, Kruszyna R, Rochelle LG, Smith RP, Chavez JE \& Mosher MD 1993 Identification of increased nitric oxide biosynthesis during pregnancy in rats. FASEB Journal 7 566-571. (https:// doi.org/10.1096/fasebj.7.6.7682524)

Cooke CL \& Davidge ST 2003 Pregnancy-induced alterations of vascular function in mouse mesenteric and uterinearteries. Biology of Reproduction 68 1072-1077. (https://doi.org/10.1095/biolreprod.102.009886)

Czeloth K, Bobjer J, Bronton K, Christofferson O, Frederiksen $\mathrm{H}$, Holmboe S, Anderson A, Juul A \& Giwercman A 2017 Comparison of testosterone measurement by the new 'gold standard' method liquid chromatography tandem mass spectrometry versus the traditionally in clinical routine used immunoassays in the prediction of symptoms of male hypogonadism. European Urology Supplements 16 e3018.

de Vries MJ, Dekker GA \& Schoemaker J 1998 Higher risk of preeclampsia in the polycystic ovary syndrome. A case control study. European Journal of Obstetrics, Gynecology and Reproductive Biology 76 91-95. (https:// doi.org/10.1016/S0301-2115(97)00164-4)

Dell'Acqua S, Mancuso S, Eriksson G \& Diczfalusy E 1966 Metabolism of retrotestosterone and testosterone by midterm human placentas perfused in situ. Biochimica et Biophysica Acta/General Subjects 130 241-248. (https://doi.org/10.1016/0304-4165(66)90028-6)

Diamant YZ, Rimon E \& Evron S 1982 High incidence of preeclamptic toxemia in patients with polycystic ovarian disease. European Journal of Obstetrics, Gynecology and Reproductive Biology 14 199-204. (https:// doi.org/10.1016/0028-2243(82)90097-1)

Diaz L, Noyola-Martinez N, Barrera D, Hernandez G, Avila E, Halhali A \& Larrea F 2009 Calcitriol inhibits TNF-alpha-induced inflammatory cytokines in human trophoblasts. Journal of Reproductive Immunology 81 17-24. (https://doi.org/10.1016/j.jri.2009.02.005)

Dokras A, Spaczynski RZ, Behrman HR \& Duleba AJ 2003 Testosterone levels in pregnant women correlate with the insulin response during the glucose tolerance test. Fertility and Sterility 79 492-497. (https://doi. org/10.1016/S0015-0282(02)04764-7)

Ferrini RL \& Barrett-Connor E 1998 Sex hormones and age: a crosssectional study of testosterone and estradiol and their bioavailable fractions in community-dwelling men. American Journal of Epidemiology 147 750-754. (https://doi.org/10.1093/oxfordjournals.aje.a009519)

Ficicioglu C \& Kutlu T 2003 The role of androgens in the aetiology and pathology of pre-eclampsia. Journal of Obstetrics \& Gynaecology 23 134-137.
Fornes R, Hu M, Maliqueo M, Kokosar M, Benrick A, Carr D, Billig H, Jansson T, Manni L \& Stener-Victorin E 2016 Maternal testosterone and placental function: effect of electroacupuncture on placental expression of angiogenic markers and fetal growth. Molecular and Cellular Endocrinology 433 1-11. (https://doi.org/10.1016/j.mce.2016.05.014)

Franks S, Gilling-Smith C, Watson H \& Willis D 1999 Insulin action in the normal and polycystic ovary. Endocrinology and Metabolism Clinics of North America 28 361-378. (https://doi.org/10.1016/S08898529(05)70074-8)

Gant NF, Hutchinson HT, Siiteri PK \& MacDonald PC 1971 Study of the metabolic clearance rate of dehydroisoandrosterone sulfate in pregnancy. American Journal of Obstetrics and Gynecology 111 555-563. (https:// doi.org/10.1016/0002-9378(71)90472-8)

Gerulewicz-Vannini D, Camero Y, Salas J \& Hernandez-Andrade E 2006 High plasmatic androgen levels in women affected with pregnancyinduced hypertension. Revista de Investigacion Clinica 58 228-233.

Ghorashi V \& Sheikhvatan M 2008 The relationship between serum concentration of free testosterone and pre-eclampsia. Endokrynologia Polska 59 390-392.

Gillham JC, Kenny LC \& Baker PN 2003 An overview of endothelium-derived hyperpolarising factor (EDHF) in normal and compromised pregnancies. European Journal of Obstetrics, Gynecology and Reproductive Biology 109 2-7. (https://doi.org/10.1016/S0301-2115(03)00044-7)

Gokina NI, Kuzina OY \& Vance AM 2010 Augmented EDHF signaling in rat uteroplacental vasculature during late pregnancy. American Journal of Physiology: Heart and Circulatory Physiology 299 H1642-H1652. (https://doi.org/10.1152/ajpheart.00227.2010)

Gonzales RJ, Krause DN \& Duckles SP 2004 Testosterone suppresses endothelium-dependent dilation of rat middle cerebral arteries. American Journal of Physiology: Heart and Circulatory Physiology 286 H552-560. (https://doi.org/10.1152/ajpheart.00663.2003)

Gonzales RJ, Ghaffari AA, Duckles SP \& Krause DN 2005 Testosterone treatment increases thromboxane function in rat cerebral arteries. American Journal of Physiology: Heart and Circulatory Physiology 289 H578-585. (https://doi.org/10.1152/ajpheart.00958.2004)

Gopalakrishnan K, Mishra JS, Chinnathambi V, Vincent KL, Patrikeev I, Motamedi M, Saade GR, Hankins GD \& Sathishkumar K 2016 Elevated testosterone reduces uterine blood flow, spiral artery elongation, and placental oxygenation in pregnant rats. Hypertension 67 630-639. (https://doi.org/10.1161/HYPERTENSIONAHA.115.06946)

Henderson BE, Bernstein L, Ross RK, Depue RH \& Judd HL 1988 The early in utero oestrogen and testosterone environment of blacks and whites: potential effects on male offspring. British Journal of Cancer 57 216-218. (https://doi.org/10.1038/bjc.1988.46)

Hertig A, Liere P, Chabbert-Buffet N, Fort J, Pianos A, Eychenne B, Cambourg A, Schumacher M, Berkane N, Lefevre G et al. 2010 Steroid profiling in preeclamptic women: evidence for aromatase deficiency. American Journal of Obstetrics and Gynecology 203 477.e471-477. e479. (https://doi.org/10.1016/j.ajog.2010.06.011)

Horie K, Takakura K, Imai K, Liao S \& Mori T 1992 Immunohistochemical localization of androgen receptor in the human endometrium, decidua, placenta and pathological conditions of the endometrium. Human Reproduction 7 1461-1466. (https://doi.org/10.1093/oxfordjournals. humrep.a137595)

Hotchkiss AK \& Nelson RJ 2007 An environmental androgen, 17betatrenbolone, affects delayed-type hypersensitivity and reproductive tissues in male mice. Journal of Toxicology and Environmental Health: Part A 70 138-140. (https://doi.org/10.1080/15287390600755091)

Hsu TY, Lan KC, Tsai CC, Ou CY, Cheng BH, Tsai MY, Kang HY, Tung YH, Wong YH \& Huang KE 2009 Expression of androgen receptor in human placentas from normal and preeclamptic pregnancies. Taiwanese Journal of Obstetrics and Gynecology 48 262-267. (https://doi.org/10.1016/ S1028-4559(09)60301-6)

Huppertz B \& Peeters LL 2005 Vascular biology in implantation and placentation. Angiogenesis 8 157-167. (https://doi.org/10.1007/s10456005-9007-8)

lavazzo C \& Vitoratos N 2010 Polycystic ovarian syndrome and pregnancy outcome. Archives of Gynecology and Obstetrics 282 235-239. (https:// doi.org/10.1007/s00404-010-1495-0)

Ishikuro M, Obara T, Metoki H, Ohkubo T, Yaegashi N, Kuriyama S \& Imai Y 2012 Blood pressure changes during pregnancy. Hypertension Research. (https://doi.org/10.1038/hr.2012.33) 
Jiang B, Kamat A \& Mendelson CR 2000 Hypoxia prevents induction of aromatase expression in human trophoblast cells in culture: potential inhibitory role of the hypoxia-inducible transcription factor Mash-2 (mammalian achaete-scute homologous protein-2). Molecular Endocrinology 14 1661-1673. (https://doi.org/10.1210/ mend.14.10.0539)

Jobe SO, Fling SN, Ramadoss J \& Magness RR 2011 A novel role for an endothelial adrenergic receptor system in mediating catecholestradiolinduced proliferation of uterine artery endothelial cells. Hypertension $\mathbf{5 8}$ 874-881. (https://doi.org/10.1161/HYPERTENSIONAHA.111.178046)

Jobe SO, Tyler CT \& Magness RR 2013 Aberrant synthesis, metabolism, and plasma accumulation of circulating estrogens and estrogen metabolites in preeclampsia implications for vascular dysfunction. Hypertension $\mathbf{6 1}$ 480-487. (https://doi.org/10.1161/HYPERTENSIONAHA.111.201624)

Kaaja R, Tikkanen MJ, Viinikka L \& Ylikorkala O 1995 Serum lipoproteins, insulin, and urinary prostanoid metabolites in normal and hypertensive pregnant women. Obstetrics and Gynecology 85 353-356. (https://doi. org/10.1016/0029-7844(94)00380-V)

Kamalanathan S, Sahoo JP \& Sathyapalan T 2013 Pregnancy in polycystic ovary syndrome. Indian Journal of Endocrinology and Metabolism 17 37-43. (https://doi.org/10.4103/2230-8210.107830)

Kawano M \& Mori N 1983 Prostacyclin producing activity of human umbilical, placental and uterine vessels. Prostaglandins 26 645-662. (https://doi.org/10.1016/0090-6980(83)90201-0)

King AJ, Olivier NB, Mohankumar PS, Lee JS, Padmanabhan V \& Fink GD 2007 Hypertension caused by prenatal testosterone excess in female sheep. American Journal of Physiology: Endocrinology and Metabolism 292 E1837-E1841. (https://doi.org/10.1152/ajpendo.00668.2006)

Kjerulff LE, Sanchez-Ramos L \& Duffy D 2011 Pregnancy outcomes in women with polycystic ovary syndrome: a metaanalysis. American Journal of Obstetrics and Gynecology 204 558.e551-558.e556. (https:// doi.org/10.1016/j.ajog.2011.03.021)

Kowalczyk TD, Cabaniss ML \& Cusmano L 1998 Association of low unconjugated estriol in the second trimester and adverse pregnancy outcome. Obstetrics and Gynecology 91 396-400. (https://doi. org/10.1016/S0029-7844(97)00677-7)

Laivuori H, Kaaja R, Rutanen EM, Viinikka L \& Ylikorkala O 1998 Evidence of high circulating testosterone in women with prior preeclampsia. Journal of Clinical Endocrinology and Metabolism 83 344-347. (https:// doi.org/10.1210/jcem.83.2.4543)

Landeros RV, Pastore MB \& Magness RR 2018 Effects of the catechol and methoxy metabolites of 17 beta-estradiol on nitric oxide production by ovine uterine artery endothelial cells. Reproductive Sciences Epub. (https://doi.org/10.1177/1933719118783265)

Lau SY, Guild SJ, Barrett CJ, Chen Q, McCowan L, Jordan V \& Chamley LW 2013 Tumor necrosis factor-alpha, interleukin-6, and interleukin-10 levels are altered in preeclampsia: a systematic review and metaanalysis. American Journal of Reproductive Immunology 70 412-427. (https://doi.org/10.1111/aji.12138

Li X, Zhang W, Lin J, Liu H, Yang Z, Teng Y, Duan S, Lin X, Xie Y, Li Y et al. 2018 Risk factors for adverse maternal and perinatal outcomes in women with preeclampsia: analysis of 1396 cases. Journal of Clinical Hypertension 20 1049-1057. (https://doi.org/10.1111/jch.13302)

Lim JH, Kim S, Lee SW, Park SY, Han JY, Chung JH, Kim MY, Yang JH \& Ryu HM 2011 Association between genetic polymorphisms in androgen receptor gene and the risk of preeclampsia in Korean women. Journal of Assisted Reproduction and Genetics 28 85-90. (https://doi.org/10.1007/ s10815-010-9485-5)

Ling S, Dai A, Williams MR, Myles K, Dilley RJ, Komesaroff PA \& Sudhir K 2002 Testosterone $(T)$ enhances apoptosis-related damage in human vascular endothelial cells. Endocrinology 143 1119-1125. (https://doi. org/10.1210/endo.143.3.8679)

Lonnebotn M, Natvig GK, Benediktsdottir B, Burgess JA, Holm M, Jogi R, Lindberg E, Macsali F, Schlunssen V, Skulstad SM et al. 2018 Polycystic ovary syndrome, body mass index and hypertensive disorders in pregnancy. Pregnancy Hypertension 11 32-37. (https://doi. org/10.1016/j.preghy.2017.12.006)

Lorentzen B, Birkeland KI, Endresen MJ \& Henriksen T 1998 Glucose intolerance in women with preeclampsia. Acta Obstetricia et Gynecologica Scandinavica 77 22-27. (https://doi.org/10.1080/00016349808565805)

Magness RR 1998 Maternal cardiovascular and other physiologic responses to the endocrinology of pregnancy. In The Endocrinology of Pregnancy
(Contemporary Endocrinology), pp 507-540. Ed FW Bazer. Totowa, NJ: Humana Press Inc. (https://doi.org/10.1007/978-1-4612-1804-3_18)

Magness RR \& Rosenfeld CR 1986 Systemic and uterine responses to alpha-adrenergic stimulation in pregnant and nonpregnant ewes. American Journal of Obstetrics and Gynecology 155 897-904. (https:// doi.org/10.1016/S0002-9378(86)80047-3)

Magness RR, Mitchell MD \& Rosenfeld CR 1990 Uteroplacental production of eicosanoids in ovine pregnancy. Prostaglandins 39 75-88. (https://doi. org/10.1016/0090-6980(90)90096-E)

Magness RR, Rosenfeld CR, Hassan A \& Shaul PW 1996 Endothelial vasodilator production by uterine and systemic arteries. I. Effects of ANG II on PGI2 and NO in pregnancy. American Journal of Physiology 270 H1914-H1923. (https://doi.org/10.1152/ ajpheart.1996.270.6.H1914)

Magness RR, Shideman CR, HabermehI DA, Sullivan JA \& Bird IM 2000 Endothelial vasodilator production by uterine and systemic arteries. V. Effects of ovariectomy, the ovarian cycle, and pregnancy on prostacyclin synthase expression. Prostaglandins and Other Lipid Mediators 60 103-118. (https://doi.org/10.1016/S0090-6980(99)00055-6)

Magness RR, Sullivan JA, Li Y, Phernetton TM \& Bird IM 2001 Endothelial vasodilator production by uterine and systemic arteries. VI. Ovarian and pregnancy effects on eNOS and $\mathrm{NO}(\mathrm{x})$. American Journal of Physiology: Heart and Circulatory Physiology 280 H1692-H1698. (https://doi. org/10.1152/ajpheart.2001.280.4.H1692)

Mains LM, Lathi RB, Burney RO \& Dahan MH 2007 Serum total testosterone levels in a patient with late onset 21-hydroxylase deficiency and a twin gestation. Fertility and Sterility 87 1212.e1215-1212.e1218. (https://doi. org/10.1016/j.fertnstert.2006.07.1545)

Makinen JI, Perheentupa A, Irjala K, Pollanen P, Makinen J, Huhtaniemi I \& Raitakari OT 2011 Endogenous testosterone and brachial artery endothelial function in middle-aged men with symptoms of late-onset hypogonadism. Aging Male 14 237-242. (https://doi.org/10.3109/1368 5538.2011.593655)

Manikkam M, Crespi EJ, Doop DD, Herkimer C, Lee JS, Yu S, Brown MB, Foster DL \& Padmanabhan V 2004 Fetal programming: prenatal testosterone excess leads to fetal growth retardation and postnatal catch-up growth in sheep. Endocrinology 145 790-798. (https://doi. org/10.1210/en.2003-0478)

Mason JI, Ushijima K, Doody KM, Nagai K, Naville D, Head JR, Milewich L, Rainey WE \& Ralph MM 1993 Regulation of expression of the 3 betahydroxysteroid dehydrogenases of human placenta and fetal adrenal. Journal of Steroid Biochemistry and Molecular Biology 47 151-159. (https://doi.org/10.1016/0960-0760(93)90069-9)

Mehrabian F \& Kelishadi R 2012 Comparison of the metabolic parameters and androgen level of umbilical cord blood in newborns of mothers with polycystic ovary syndrome and controls. Journal of Research in Medical Sciences 17 207-211.

Metz TD, Allshouse AA, Euser AG \& Heyborne KD 2014 Preeclampsia in high risk women is characterized by risk group-specific abnormalities in serum biomarkers. American Journal of Obstetrics and Gynecology 211 512.e511-512.e516. (https://doi.org/10.1016/j.ajog.2014.04.027)

Meulenberg PM \& Hofman JA 1991 Maternal testosterone and fetal sex. Journal of Steroid Biochemistry and Molecular Biology 39 51-54. (https:// doi.org/10.1016/0960-0760(91)90012-T)

Milczarek R, Sokolowska E, Hallmann A, Kaletha K \& Klimek J 2008 $\mathrm{NADPH}$ - and iron-dependent lipid peroxidation inhibit aromatase activity in human placental microsomes. Journal of Steroid Biochemistry and Molecular Biology 110 230-235. (https://doi.org/10.1016/j. jsbmb.2007.11.004)

Miller NR, Garry D, Cohen HW \& Figueroa R 2003 Serum androgen markers in preeclampsia. Journal of Reproductive Medicine 48 225-229.

Mitchell F 2012 Reproductive endocrinology: Mass spectrometry 'gold standard' for measuring steroid sex hormones? Nature Reviews in Endocrinology 8320.

Mori T, Watanabe K, Iwasaki A, Kimura C, Matsushita H, Shinohara K \& Wakatsuki A 2014 Differences in vascular reactivity between pregnant women with chronic hypertension and preeclampsia. Hypertension Research 37 145-150. (https://doi.org/10.1038/hr.2013.131)

Murji A, Proctor LK, Paterson AD, Chitayat D, Weksberg R \& Kingdom J 2012 Male sex bias in placental dysfunction. American Journal of Medical Genetics: Part A 158A 779-783. (https://doi.org/10.1002/ ajmg.a.35250) 
Myatt L 2002 Role of placenta in preeclampsia. Endocrine 19 103-111. (https://doi.org/10.1385/ENDO:19:1:103)

Naden RP \& Rosenfeld CR 1981 Effect of angiotensin II on uterine and systemic vasculature in pregnant sheep. Journal of Clinical Investigation 68 468-474. (https://doi.org/10.1172/JCl110277)

Nakao J, Change WC, Murota SI \& Orimo H 1981 Testosterone inhibits prostacyclin production by rat aortic smooth muscle cells in culture. Atherosclerosis 39 203-209. (https://doi.org/10.1016/00219150(81)90070-8)

Nelson SH, Steinsland OS, Wang Y, Yallampalli C, Dong YL \& Sanchez JM 2000 Increased nitric oxide synthase activity and expression in the human uterine artery during pregnancy. Circulation Research 87 406-411. (https://doi.org/10.1161/01.RES.87.5.406)

Orlando EF, Kolok AS, Binzcik GA, Gates JL, Horton MK, Lambright CS, Gray LE Jr, Soto AM \& Guillette LJ Jr 2004 Endocrine-disrupting effects of cattle feedlot effluent on an aquatic sentinel species, the fathead minnow. Environmental Health Perspectives 112 353-358. (https://doi. org/10.1289/ehp.6591)

Osol G \& Mandala M 2009 Maternal uterine vascular remodeling during pregnancy. Physiology 24 58-71. (https://doi.org/10.1152/ physiol.00033.2008)

Palei AC, Spradley FT, Warrington JP, George EM \& Granger JP 2013 Pathophysiology of hypertension in pre-eclampsia: a lesson in integrative physiology. Acta Physiologica 208 224-233. (https://doi.org/10.1111/ apha.12106)

Palomba S, Falbo A, Russo T, Battista L, Tolino A, Orio F \& Zullo F 2010 Uterine blood flow in pregnant patients with polycystic ovary syndrome: relationships with clinical outcomes. British Journal of Obstetrics and Gynaecology 117 711-721. (https://doi.org/10.1111/j.14710528.2010.02525.x)

Palomba S, Russo T, Falbo A, Di CA, Amendola G, Mazza R, Tolino A, Zullo F, Tucci L \& La Sala GB 2012 Decidual endovascular trophoblast invasion in women with polycystic ovary syndrome: an experimental case-control study. Journal of Clinical Endocrinology and Metabolism 97 2441-2449. (https://doi.org/10.1210/jc.2012-1100)

Pan T, He G, Chen M, Bao C, Chen Y, Liu G, Zhou M, Li S, Xu W \& Liu X 2017 Abnormal CYP11A1 gene expression induces excessive autophagy, contributing to the pathogenesis of preeclampsia. Oncotarget 8 89824-89836. (https://doi.org/10.18632/oncotarget.21158)

Park KM, Kim JI, Ahn Y, Bonventre AJ \& Bonventre JV 2004 Testosterone is responsible for enhanced susceptibility of males to ischemic renal injury. Journal of Biological Chemistry 279 52282-52292. (https://doi. org/10.1074/jbc.M407629200)

Parks LG, Lambright CS, Orlando EF, Guillette LJ Jr, Ankley GT \& Gray LE Jr 2001 Masculinization of female mosquitofish in Kraft mill effluentcontaminated Fenholloway River water is associated with androgen receptor agonist activity. Toxicological Sciences 62 257-267. (https://doi. org/10.1093/toxsci/62.2.257)

Pasquali R, Gambineri A, Biscotti D, Vicennati V, Gagliardi L, Colitta D, Fiorini S, Cognigni GE, Filicori M \& Morselli-Labate AM 2000 Effect of long-term treatment with metformin added to hypocaloric diet on body composition, fat distribution, and androgen and insulin levels in abdominally obese women with and without the polycystic ovary syndrome. Journal of Clinical Endocrinology and Metabolism 85 2767-2774. (https://doi.org/10.1210/jcem.85.8.6738)

Perez-Sepulveda A, Monteiro LJ, Dobierzewska A, Espana-Perrot PP, Venegas-Araneda P, Guzman-Rojas AM, Gonzalez MI, PalominosRivera M, Irarrazabal CE, Figueroa-Diesel H et al. 2015 Placental aromatase is deficient in placental ischemia and preeclampsia. PLOS ONE 10 e0139682. (https://doi.org/10.1371/journal.pone. 0139682)

Potischman N, Troisi R, Thadhani R, Hoover RN, Dodd K, Davis WW, Sluss PM, Hsieh CC \& Ballard-Barbash R 2005 Pregnancy hormone concentrations across ethnic groups: implications for later cancer risk. Cancer Epidemiology, Biomarkers and Prevention 14 1514-1520. (https://doi.org/10.1158/1055-9965.EPI-04-0869)

Powe CE, Levine RJ \& Karumanchi SA 2011 Preeclampsia, a disease of the maternal endothelium: the role of antiangiogenic factors and implications for later cardiovascular disease. Circulation 123 2856-2869. (https://doi.org/10.1161/CIRCULATIONAHA.109.853127)

Recabarren SE, Rojas-Garcia PP, Recabarren MP, Alfaro VH, Smith R, Padmanabhan V \& Sir-Petermann T 2008 Prenatal testosterone excess reduces sperm count and motility. Endocrinology 149 6444-6448. (https://doi.org/10.1210/en.2008-0785)

Reckelhoff JF, Zhang H \& Granger JP 1998 Testosterone exacerbates hypertension and reduces pressure-natriuresis in male spontaneously hypertensive rats. Hypertension 31 435-439. (https://doi.org/10.1161/01. HYP.31.1.435)

Roberts JM \& Redman CW 1993 Pre-eclampsia: more than pregnancyinduced hypertension. Lancet 341 1447-1451. (https://doi. org/10.1016/0140-6736(93)90889-O)

Roberts JM, Taylor RN \& Goldfien A 1991 Clinical and biochemical evidence of endothelial cell dysfunction in the pregnancy syndrome preeclampsia. American Journal of Hypertension 4 700-708. (https:// doi.org/10.1093/ajh/4.8.700)

Rohrmann S, Sutcliffe CG, Bienstock JL, Monsegue D, Akereyeni F, Bradwin G, Rifai N, Pollak MN, Agurs-Collins T \& Platz EA 2009 Racial variation in sex steroid hormones and the insulin-like growth factor axis in umbilical cord blood of male neonates. Cancer Epidemiology, Biomarkers and Prevention 18 1484-1491. (https://doi. org/10.1158/1055-9965.EPI-08-0817)

Rosenfeld CR, Morriss FH Jr, Makowski EL, Meschia G \& Battaglia FC 1974 Circulatory changes in the reproductive tissues of ewes during pregnancy. Gynecologic Investigation 5 252-268. (https://doi. org/10.1159/000301658)

Rosing U \& Carlstrom K 1984 Serum levels of unconjugated and total oestrogens and dehydroepiandrosterone, progesterone and urinary oestriol excretion in pre-eclampsia. Gynecologic and Obstetric Investigation 18 199-205. (https://doi.org/10.1159/000299081)

Salam RA, Das JK, Ali A, Bhaumik S \& Lassi ZS 2015 Diagnosis and management of preeclampsia in community settings in low and middleincome countries. Journal of Family Medicine and Primary Care 4 501-506. (https://doi.org/10.4103/2249-4863.174265)

Salamalekis E, Bakas P, Vitoratos N, Eleptheriadis M \& Creatsas G 2006 Androgen levels in the third trimester of pregnancy in patients with preeclampsia. European Journal of Obstetrics, Gynecology and Reproductive Biology 126 16-19. (https://doi.org/10.1016/j. ejogrb.2005.07.007)

Samadi AR, Mayberry RM \& Reed JW 2001 Preeclampsia associated with chronic hypertension among African-American and White women. Ethnicity and Disease 11 192-200.

Sarkar P, Bergman K, Fisk NM, O'Connor TG \& Glover V 2007 Amniotic fluid testosterone: relationship with cortisol and gestational age. Clinical Endocrinology 67 743-747. (https://doi.org/10.1111/j.13652265.2007.02955.x)

Sarkar P, Bergman K, O'Connor TG \& Glover V 2008 Maternal antenatal anxiety and amniotic fluid cortisol and testosterone: possible implications for foetal programming. Journal of Neuroendocrinology 20 489-496. (https://doi.org/10.1111/j.1365-2826.2008.01659.x)

Sathishkumar K, Balakrishnan M, Gao HJ \& Yallampalli C 2011 a Elevated testosterone levels during pregnancy induce preeclampsia-like syndrome in pregnant rats. Reproductive Sciences 18 359a.

Sathishkumar K, Elkins R, Chinnathambi V, Gao H, Hankins GD \& Yallampalli C $2011 b$ Prenatal testosterone-induced fetal growth restriction is associated with down-regulation of rat placental amino acid transport. Reproductive Biology and Endocrinology 9 110. (https:// doi.org/10.1186/1477-7827-9-110)

Sathishkumar K, Elkins R, Yallampalli U, Balakrishnan M \& Yallampalli C 2011c Fetal programming of adult hypertension in female rat offspring exposed to androgens in utero. Early Human Development 87 407-414. (https://doi.org/10.1016/j.earlhumdev.2011.03.001)

Sathishkumar K, Balakrishnan M, Chinnathambi V, Chauhan M, Hankins GD \& Yallampalli C 2012 Fetal sex-related dysregulation in testosterone production and their receptor expression in the human placenta with preeclampsia. Journal of Perinatology 32 328-335. (https://doi.org/10.1038/jp.2011.101)

Schiffer B, Daxenberger A, Meyer K \& Meyer HH 2001 The fate of trenbolone acetate and melengestrol acetate after application as growth promoters in cattle: environmental studies. Environmental Health Perspectives 109 1145-1151. (https://doi.org/10.1289/ehp. 011091145)

Seely EW \& Solomon CG 2003 Insulin resistance and its potential role in pregnancy-induced hypertension. Journal of Clinical Endocrinology and Metabolism 88 2393-2398. (https://doi.org/10.1210/jc.2003-030241) 
Serin IS, Kula M, Basbug M, Unluhizarci K, Gucer S \& Tayyar M 2001 Androgen levels of preeclamptic patients in the third trimester of pregnancy and six weeks after delivery. Acta Obstetricia et Gynecologica Scandinavica 80 1009-1013. (https://doi.org/10.1034/j.16000412.2001.801107.x)

Shao X, Liu Y, Liu M, Wang Y, Yan L, Wang H, Ma L, Li YX, Zhao Y \& Wang YL 2017 Testosterone represses estrogen signaling by upregulating miR-22: a mechanism for imbalanced steroid hormone production in preeclampsia. Hypertension 69 721-730. (https://doi.org/10.1161/ HYPERTENSIONAHA.116.08468)

Sharifzadeh F, Kashanian M \& Fatemi F 2012 A comparison of serum androgens in pre-eclamptic and normotensive pregnant women during the third trimester of pregnancy. Gynecological Endocrinology 28 834-836.

Sir-Petermann T, Maliqueo M, Angel B, Lara HE, Perez-Bravo F \& Recabarren SE 2002 Maternal serum androgens in pregnant women with polycystic ovarian syndrome: possible implications in prenatal androgenization. Human Reproduction 17 2573-2579. (https://doi. org/10.1093/humrep/17.10.2573)

Sir-Petermann T, Hitchsfeld C, Maliqueo M, Codner E, Echiburu B, Gazitua R, Recabarren S \& Cassorla F 2005 Birth weight in offspring of mothers with polycystic ovarian syndrome. Human Reproduction 20 2122-2126. (https://doi.org/10.1093/humrep/dei009)

Sladek SM, Magness RR \& Conrad KP 1997 Nitric oxide and pregnancy. American Journal of Physiology 272 R441-R463. (https://doi. org/10.1152/ajpregu.1997.272.2.R441)

Smith AS, Birnie AK \& French JA 2010 Maternal androgen levels during pregnancy are associated with early-life growth in Geoffroy's marmosets, Callithrix geoffroyi. General and Comparative Endocrinology 166 307-313. (https://doi.org/10.1016/j.ygcen.2009.10.008)

Stanhewicz AE, Jandu S, Santhanam L \& Alexander LM 2017 Alterations in endothelin type $\mathrm{B}$ receptor contribute to microvascular dysfunction in women who have had preeclampsia. Clinical Science 131 2777-2789. (https://doi.org/10.1042/CS20171292)

Stark MJ, Dierkx L, Clifton VL \& Wright IM 2006 Alterations in the maternal peripheral microvascular response in pregnancies complicated by preeclampsia and the impact of fetal sex. Journal of the Society for Gynecologic Investigation 13 573-578. (https://doi.org/10.1016/j. jsgi.2006.06.006)

Steckler T, Wang J, Bartol FF, Roy SK \& Padmanabhan V 2005 Fetal programming: prenatal testosterone treatment causes intrauterine growth retardation, reduces ovarian reserve and increases ovarian follicular recruitment. Endocrinology 146 3185-3193. (https://doi.org/10.1210/ en.2004-1444)

Steier JA, Ulstein M \& Myking OL 2002 Human chorionic gonadotropin and testosterone in normal and preeclamptic pregnancies in relation to fetal sex. Obstetrics and Gynecology 100 552-556. (https://doi. org/10.1097/00006250-200209000-00024)

Sun M, Maliqueo M, Benrick A, Johansson J, Shao R, Hou L, Jansson T, Wu X \& Stener-Victorin E 2012 Maternal androgen excess reduces placental and fetal weights, increases placental steroidogenesis, and leads to long-term health effects in their female offspring. American Journal of Physiology: Endocrinology and Metabolism 303 E1373E1385. (https://doi.org/10.1152/ajpendo.00421.2012)

Sutton-Tyrrell K, Zhao X, Santoro N, Lasley B, Sowers M, Johnston J, Mackey R \& Matthews K 2010 Reproductive hormones and obesity: 9 years of observation from the Study of Women's Health across the Nation. American Journal of Epidemiology 171 1203-1213. (https://doi. org/10.1093/aje/kwq049)

Svartberg J, Midtby M, Bonaa KH, Sundsfjord J, Joakimsen RM \& Jorde R 2003 The associations of age, lifestyle factors and chronic disease with testosterone in men: the Tromso Study. European Journal of Endocrinology 149 145-152. (https://doi.org/10.1530/eje.0.1490145)

Sykes SD, Pringle KG, Zhou A, Dekker GA, Roberts CT, Lumbers ER \& SCOPE Consortium 2014 Fetal sex and the circulating renin-angiotensin system during early gestation in women who later develop preeclampsia or gestational hypertension. Journal of Human Hypertension $\mathbf{2 8}$ 133-139. (https://doi.org/10.1038/jhh.2013.51)

Takeyama J, Sasano H, Suzuki T, linuma K, Nagura H \& Andersson S 1998 17Beta-hydroxysteroid dehydrogenase types 1 and 2 in human placenta: an immunohistochemical study with correlation to placental development. Journal of Clinical Endocrinology and Metabolism 83 3710-3715. (https://doi.org/10.1210/jcem.83.10.5212)

Tamimi R, Lagiou P, Vatten LJ, Mucci L, Trichopoulos D, Hellerstein S, Ekbom A, Adami HO \& Hsieh CC 2003 Pregnancy hormones, preeclampsia, and implications for breast cancer risk in the offspring. Cancer Epidemiology, Biomarkers and Prevention 12 647-650.

Thornburg KL, Jacobson SL, Giraud GD \& Morton MJ 2000 Hemodynamic changes in pregnancy. Seminars in Perinatology 24 11-14. (https://doi. org/10.1016/S0146-0005(00)80047-6)

Troisi R, Potischman N, Roberts JM, Ness R, Crombleholme W, Lykins D, Siiteri P \& Hoover RN 2003 Maternal serum oestrogen and androgen concentrations in preeclamptic and uncomplicated pregnancies. International Journal of Epidemiology 32 455-460. (https://doi. org/10.1093/ije/dyg094)

Turnipseed MR, Bentley K \& Reynolds JW 1976 Serum dehydroepiandrosterone sulfate in premature infants and infants with intrauterine growth retardation. Journal of Clinical Endocrinology and Metabolism 43 1219-1225. (https://doi.org/10.1210/jcem-43-6-1219)

Veiga-Lopez A, Steckler TL, Abbott DH, Welch KB, MohanKumar PS, Phillips DJ, Refsal K \& Padmanabhan V 2011 Developmental programming: impact of excess prenatal testosterone on intrauterine fetal endocrine milieu and growth in sheep. Biology of Reproduction $\mathbf{8 4}$ 87-96. (https://doi.org/10.1095/biolreprod.110.086686)

Vyas AK, Hoang V, Padmanabhan V, Gilbreath E \& Mietelka KA 2016 Prenatal programming: adverse cardiac programming by gestational testosterone excess. Scientific Reports 6 28335. (https://doi.org/10.1038/ srep28335)

Wan J, Hu Z, Zeng K, Yin Y, Zhao M, Chen M \& Chen Q 2018 The reduction in circulating levels of estrogen and progesterone in women with preeclampsia. Pregnancy Hypertension 11 18-25. (https://doi. org/10.1016/j.preghy.2017.12.003)

Wang YC, Su HY, Liu JY, Chang FW \& Chen CH 2005 Maternal and female fetal virilization caused by pregnancy luteomas. Fertility and Sterility $\mathbf{8 4}$ 509. (https://doi.org/10.1016/j.fertnstert.2005.02.029)

Warmann S, Roth C, Gluer S \& Fuchs J 2000 Congenital adrenal hyperplasia associated with maternal pregnancy luteoma and the AntleyBixler syndrome. Journal of Pediatric Surgery 35 528-530. (https://doi. org/10.1016/S0022-3468(00)90232-X)

Williams DJ, Vallance PJ, Neild GH, Spencer JA \& Imms FJ 1997 Nitric oxide-mediated vasodilation in human pregnancy. American Journal of Physiology 272 H748-H752. (https://doi.org/10.1152/ ajpheart.1997.272.2.H748)

Yanes LL, Sartori-Valinotti JC, Iliescu R, Romero DG, Racusen LC, Zhang H \& Reckelhoff JF 2009 Testosterone-dependent hypertension and upregulation of intrarenal angiotensinogen in Dahl salt-sensitive rats. American Journal of Physiology: Renal Physiology 296 F771-F779. (https://doi.org/10.1152/ajprenal.90389.2008)

Yu RM, Chaturvedi G, Tong SK, Nusrin S, Giesy JP, Wu RS \& Kong RY 2015 Evidence for microRNA-mediated regulation of steroidogenesis by hypoxia. Environmental Science and Technology 49 1138-1147. (https:// doi.org/10.1021/es504676s)

Received 29 May 2018

First decision 3 July 2018

Revised manuscript received 28 August 2018

Accepted 12 September 2018 